\title{
РЕГІОНАЛЬНІ МІГРАЦІЙНІ ПРОЦЕСИ ТА ЗАХВОРЮВАНІСТЬ НА ДВОСТУЛКОВИЙ АОРТАЛЬНИЙ КЛАПАН У ДІТЕЙ ЗАПОРІЗЬКОЇ ОБЛАСТІ
}

\author{
Запорізький державний медичний університет
}

๑А. В. Каменщик

РЕЗЮмЕ. Формування вроджених вад серця (ВВС) відбувається під впливом генетичних, середовищних та демографічних чинників. Під впливом міграційних процесів, завдяки змінам у внутрішньопопуляційній гетерозиготності збільшується мутаційне навантаження, що, у свою чергу, призводить до змін у формуванні захворюваності на вроджені вади серця (ВВС), у тому числі двостулковий аортальний клапан (ДАК).

Метою дослідження стало встановлення взаємозв'язків між основними показниками міграції населення та захворюваністю на двостулковий аортальний клапан (ДАК) у мешканців міст та сільських районів Запорізької області, а також внесків у неї міграційних процесів.

Матеріал і методи. На підставі даних про захворюваність на найпоширеніші ВВС серед дитячого населення Запорізької області, включаючи двостулковий аортальний клапан (ДАК), та даних обласного управління статистики щодо показників міграції населення регіону, з використанням методів кореляційного та регресійного аналізу був проаналізований вплив цих показників на захворюваність на ДАК.

Результати. Встановлене переважання внутрішньорегіональної та зовнішньої міграції у мешканців міст регіону при достовірному збільшенні в них захворюваності на ДАК. Найбільші внески у захворюваність, у тому числі порівняно з іншими ВВС, має число прибулих та вибулих осіб при зовнішньорегіональній міграції. Встановлений вплив окремих міграційних процесів у захворюваність на ДАК може слугувати непрямим показником мутаційного навантаження у окремих субпопуляціях України.

КЛючОВІ СЛОВА: двостулковий аортальний клапан; діти; захворюваність на вроджені вади серця; сільське та міське населення; внески міграційних процесів.

Вступ. Загальновідомо, що формування вроджених вад серця (ВВС) відбувається під впливом генетичних, середовищних та демографічних чинників [1]. Демографічна ситуація в Україні під впливом економічних чинників швидко змінюється. Це призводить до відповідних змін у міграції населення із зростанням урбаністичного компонента, завдяки чому в сільських районах також значно змінюються міграційні складові популяції, що призводить до негативних наслідків гетерозису [2,3]. Підвищується рівень внутрішньопопуляційної гетерозиготності, що може суттєво впливати на загальне мутаційне навантаження, у тому числі створювати умови для підвищення захворюваності на генетично обумовлені $\mathrm{BBC}[4,5]$. Здається, що в даних умовах є доцільним складання на системних засадах еталону поширеності ВBC у взаємозв'язку із демографічними показниками для подальшого спостереження, прогнозування і корекції негативних змін, що впливають на здоров'я популяції відповідного регіону. Вади серця, що перебігають 3 аномаліями серцевих клапанів, найчастіше зустрічаються у абортусів 3 патологією плаценти (у більш ніж 50 \% випадків) [6], що може бути непрямим свідченням впливу генетичних чинників на формування захворюваності, які, у свою чергу, перебувають також під контролем як міжрегіональних, так і внутрішньорегіональних міграційних процесів. У попередніх дослідженнях нами було показано переважання поширеності BBC із клапанними аномаліями у мешканців міст південно-східного регіону України, порівняно із сільськими районами $(8,29 \%$ та 6,81 \% відповідно) [7], що також може бути пов'язане із відомою різницею у спрямованості факторів міграції.

Мета дослідження - встановлення взаємозв'язків між основними показниками міграції населення та захворюваністю на двостулковий аортальний клапан (ДАК) у мешканців міст та сільських районів Запорізької області, а також внесків у неї міграційних процесів.

Матеріал і методи дослідження. Для реалізації поставленої мети була створена база даних щодо захворюваності на ВВС у дітей регіону, де була відображена поширеність та захворюваність на клапанні ВВС відповідно територіально-адміністративному розподілу 21 сільського району та 5 міст Запорізької області станом на 2011 рік при сталих демографічних та економічних тенденціях на цей період. Основні показники міграції населення, такі як кількість народжених та померлих, число шлюбів та розлучень на 1000 мешканців, кількість померлих осіб до 1 року та смертність до 1 року на 1000 мешканців були надані головним управлінням статистики області (http://www.zp. ukrstat.gov.ua). Статистичну обробку результатів проводили за допомогою програми Statistica 6.03 використанням критерію Стьюдента, методів кореляційного аналізу та множинної регресії. 
Огляди літератури, оригінальні дослідження, погляд на проблему

Результати й обговорення. Дослідження середньорічних міграційних процесів у Запорізький області виявило суттєві розбіжності між показниками мешканців міст та сільських районів. Ці дані наведені у таблиці 1. Як видно з цієї таблиці, міська внутрішньорегіональна міграція приводила до збільшення прибулих осіб у містах на 742 особи за рік, тоді як у сільських районах до зменшення на 601 особу відповідно. В містах та сільських районах зовнішня міграція була практично однаковою із зменшенням населення на 373 та 390 осіб відповідно Отже, у Запорізький області міграційні процеси у сільського населення та населення міста відрізнялися та мали протилежну спрямованість, як при внутрішньорегіональній, так і при зовнішній мігра- ції. У мешканців міст, порівняно із мешканцями сільської місцевості, достовірно вищими були такі показники як число прибулих $((1460 \pm 577,84)$ та

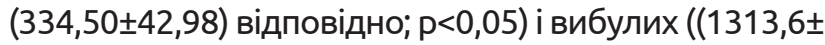
$650,28)$ та $(372,06 \pm 43,02)$ відповідно; $p<0,05)$ при міг-

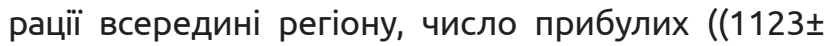
$518,07)$ та $(125,06 \pm 14,11)$ відповідно; $р<0,05)$ і вибулих ((1197,6士612,73) відповідно; р<0,05) при зовнішньорегіональній міграції, кількість померлих осіб до 1 року $((17,8 \pm 7,36)$ та $(3,87 \pm 0,75)$ відповідно; $p<0,05)$, та достовірно нижчими кількість померлих на 1000 осіб $((13,28 \pm 1,36)$ та $(17,69 \pm 0,62)$ відповідно; $p<0,05)$. Слід також зазначити, що захворюваність на різні види ВBC значно відрізнялася у мешканців міст та сільської місцевості області. Ці дані наведені у таблиці 2.

Таблиця 1. Середні показники річних міграційних складових у Запорізький області (станом на 2011 рік)

\begin{tabular}{|l|c|c|c|c|}
\hline \multirow{2}{*}{\multicolumn{1}{|c|}{ Показники }} & \multicolumn{2}{c|}{ Міська міграція } & \multicolumn{2}{c|}{ Сільська міграція } \\
\cline { 2 - 5 } & середня кількість & всього & середня кількість & всього \\
\hline Кількість народжених на 1000 & $10,06 \pm 0,49$ & 50,3 & $11,32 \pm 0,26$ & 181,1 \\
\hline Кількість померлих на 1000 & $13,28 \pm 1,36^{*}$ & 66,4 & $17,69 \pm 0,62$ & 283 \\
\hline Число шлюбів на 1000 & $7,74 \pm 0,99$ & 38,7 & $5,79 \pm 0,31$ & 92,6 \\
\hline Число розлучень на 1000 & $1,76 \pm 0,21$ & 8,8 & $1,14 \pm 0,07$ & 18,3 \\
\hline Число прибулих при регіональній міграції & $1460 \pm 577,84^{*}$ & 7300 & $334,50 \pm 42,98$ & 5352 \\
\hline Число вибулих при регіональній міграції & $1313,6 \pm 650,28^{*}$ & 6568 & $372,06 \pm 43,02$ & 5953 \\
\hline Число прибулих при зовнішній міграції & $1123 \pm 518,07^{*}$ & 5615 & $125,06 \pm 14,11$ & 2001 \\
\hline Число вибулих при зовнішній міграції & $1197,6 \pm 612,73$ & 5988 & $149,44 \pm 14,85$ & 2391 \\
\hline Померло до 1 року осіб & $17,8 \pm 7,36^{*}$ & 89 & $3,87 \pm 0,75$ & 62 \\
\hline Смертність до 1 року на 1000 & $0,1 \pm 0,03$ & 0,56 & $0,12 \pm 0,18$ & 1,882 \\
\hline
\end{tabular}

Примітка. * $-p<0,05$.

Таблиця 2. Захворюваність на найбільш поширені ВВС у мешканців міст та сільських районів Запорізької області

\begin{tabular}{|c|c|c|c|}
\hline Тип ВВС & Загальна захворюваність & $\begin{array}{c}\text { Захворюваність міського } \\
\text { населення }\end{array}$ & $\begin{array}{c}\text { Захворюваність сільського } \\
\text { населення }\end{array}$ \\
\hline ДМПП & 0,07 & 0,09 & 0,06 \\
\hline ДМШП & 0,04 & 0,06 & 0,04 \\
\hline ДАК & 0,018 & $0,05^{*}$ & 0,009 \\
\hline КАА & 0,006 & $0,012^{*}$ & 0,004 \\
\hline ВАП & 0,025 & 0,04 & 0,02 \\
\hline СЛа & 0,008 & $0,01^{*}$ & 0,006 \\
\hline
\end{tabular}

Примітка. *- р<0,05; ДМПП - дефект міжпередсердної перетинки; ДМшП - дефект міжшлуночкової перетинки; ВАП - відкрита артеріальна протока; СТЛА - стеноз легеневої артерії; КоА -коарктація аорти.

Таблиця 2 свідчить, що у міського населення регіону захворюваність на всі види найпоширеніших ВBC перебільшувала цей показник у сільського населення, при цьому найсуттєвіші відмінності були отримані для ДАК (0,05 та 0,009 відповідно; р<0,05), коарктації аорти $(0,012$ та 0,004 відповідно; $\mathrm{p<0,05),} \mathrm{стенозу} \mathrm{легеневої} \mathrm{артерії}$ (0,01 та 0,006 відповідно; p<0,05). У зв'язку з вищенаведеним були досліджені взаємозв'язки показників міграційних процесів та захворюваності на вроджені вади серця у дітей Запорізької області. Результати кореляційного аналізу цих даних наведені на рисунках 1 та 2.

Як можна побачити з рисунка 1, у дітей Запорізької області, що мали ДАК, достовірні кореляції були отримані між показниками зовнішньої міграції як з числом прибулих $(R=0,61 ; p=0,003)$ так й з числом вибулих (R=0,56; $p=0,008)$ мешканців. При інших BBC зазначені кореляції при зовнішній міграції носили переважно однобічний характер і стосувались 
Огляди літератури, оригінальні дослідження, погляд на проблему
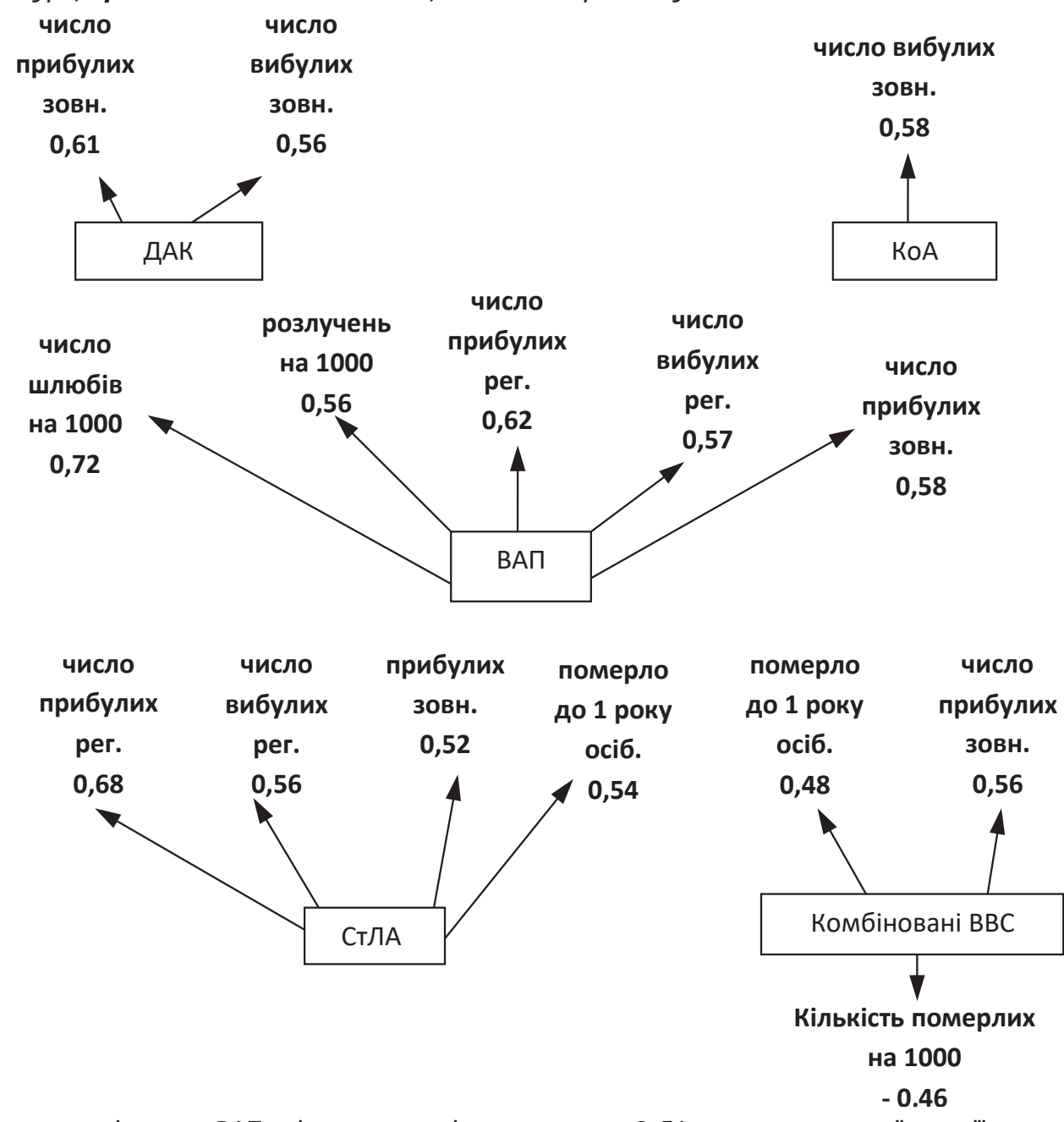

Примітка. КоА - коарктація аорти; ВАП - відкрита артеріальна протока; СТЛА - стеноз легеневої артерії; рег. - внутрішньорегіональна міграція; зовн. - зовнішня міграція.

Рис. 1. Достовірні коефіцієнти кореляції $(p<0,05)$, отримані між захворюваністю на вроджені вади серця та міграційними показниками у дітей Запорізької області.

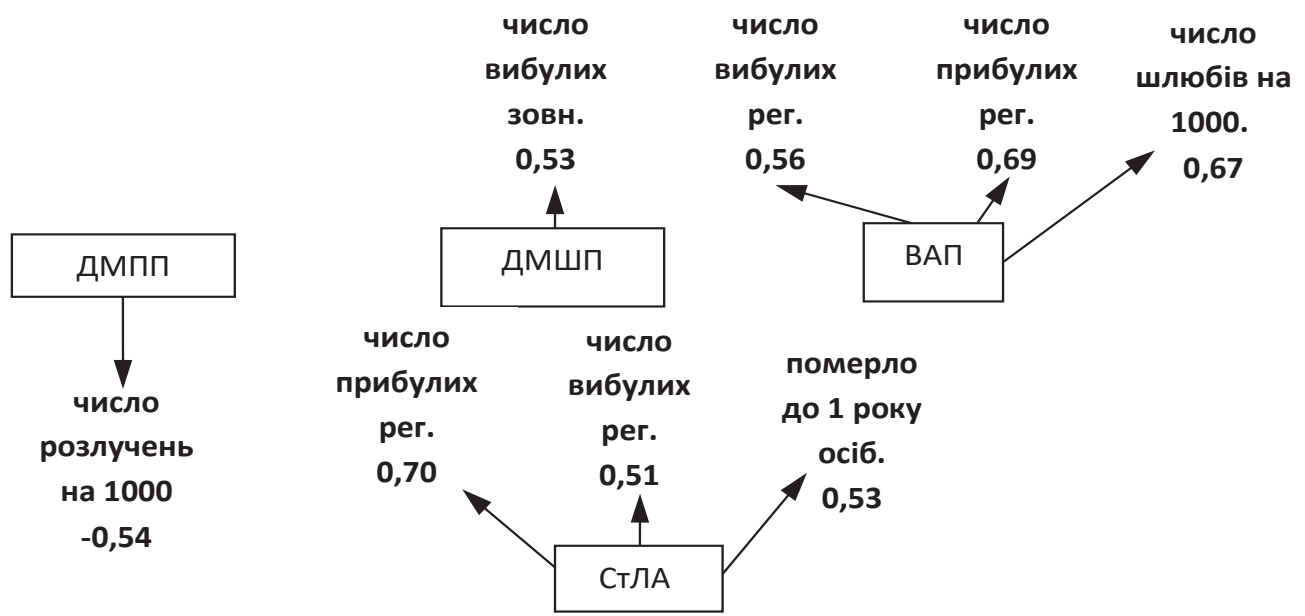

Примітка. ДМПП - дефект міжпередсердної перетинки; ДМшП - дефект міжшлуночкової перетинки; ВАП - відкрита артеріальна протока; СТЛА - стеноз легеневої артерії; рег. - регіональна міграція; зовн. - зовнішня міграція

Рис. 2. Достовірні коефіцієнти кореляції (p<0,05), отримані між захворюваністю на вроджені вади серця та міграційними показниками у дітей сільських районів Запорізької області. 
Огляди літератури, оригінальні дослідження, погляд на проблему

прибулих мешканців для відкритої артеріальної протоки (ВАП), ( $R=0,58 ; \mathrm{p}=0,01)$, стенозу легеневої артерії (СтЛа), ( $R=0,52 ; \mathrm{p}=0,001)$ та комбінованих $\mathrm{BBC}(\mathrm{R}=0,56 ; \mathrm{P}=0,01)$ та, відповідно, вибулих для коарктації аорти (KoA) $(R=0,58 ; p=0,006)$. Слід також зазначити, що для септальних ВBC достовірних значень креляційних коефіціентів отримано не було.

У мешканців сільських районів Запорізької області не було отримано достовірних кореляцій основних показників міграції з ДАК (рис. 2) при наявності кореляційних взаємозв'язків зазначених параметрів з дефектом міжпередсердної перетинки (ДМПП), числом розлучень; $(R=-0,54 ; p=0,03)$, дефектом міжшлуночкової перетинки (ДМШП) з числом вибулих при зовнішній міграції; $(R=0,53 ; p=0,04)$, ВАП з числом вибулих при внутрішньорегіональній міграції $(R=0,56 ; p=0,04)$, числом прибулих при внутрішньорегіональній міграції $(R=0,69 ; p=0,007)$, числом шлюбів на 1000 мешканців $(R=0,67 ; p=0,009)$, СТЛА з числом прибулих при регіональній міграції $(\mathrm{R}=0,70 ; \mathrm{p}=0,002)$, числом вибулих при регіональ- ній міграції $(R=0,51 ; p=0,04)$, числом померлих осі6 у віці до 1 року $(R=0,53 ; p=0,03)$.

Виходячи з вищенаведеного можна передбачати більш суттєвий вплив міграційних процесів на формування захворюваності на ДАК у дітей мешканців міст регіону. За допомогою регресійного аналізу були визначені внески міграційних показників у захворюваність на ДАК у дітей Запорізького регіону. Ці дані наведені у таблиці 3 та на рисунку 3. Встановлено, що у дітей Запорізької області найбільші внески у захворюваність на ДАК серед показників міграції були пов'язані із як кількістю вибулих, так і прибулих осіб при зовнішній міграції. При цьому внески показника вибулих осіб набували достовірних значень $\left(b^{2}=-7,13\right.$; $p=0,04)$, а прибулих залишались на рівні тенденції $\left(b^{2}=6,43 ; p=0.06\right)$. Слід також зазначити різну направленість вказаних внесків щодо захворюваності на ДАК і можливість збільшення показника захворюваності при зростанні зовнішньої міграції населення регіону.

Таблиця 3. Коефіцієнти множинної регресії (b²), що характеризують внески основних міграційних процесів у захворюваність на ДАК у дітей Запорізької області

\begin{tabular}{|l|c|c|c|c|c|c|}
\hline \multicolumn{7}{|c|}{$\mathrm{R}=0,86 ; \mathrm{R}^{2}=0,73$; скоригований $\mathrm{R}^{2}=0,46$} \\
\hline & $\mathrm{b}^{2}$ & $\mathrm{~b}^{2 \pm} \mathrm{m}$ & $\mathrm{b}$ & $\mathrm{b} \pm \mathrm{m}$ & $\mathrm{t}(10)$ & $\mathrm{p}$-value \\
\hline Interсерt & & & 0,16 & 0,11 & 1,41 & 0,19 \\
\hline Кількість народжених на 1000 & $-0,41$ & 0,28 & $-0,008$ & 0,006 & $-1,44$ & 0,18 \\
\hline Кількість померлих на 1000 & $-0,40$ & 0,32 & $-0,003$ & 0,002 & $-1,26$ & 0,24 \\
\hline Число шлюбів на 1000 & $-0,18$ & 0,48 & $-0,003$ & 0,007 & $-0,38$ & 0,71 \\
\hline Число розлучень на 1000 & $-0,20$ & 0,38 & $-0,01$ & 0,02 & $-0,52$ & 0,61 \\
\hline Число прибулих рег. & 1,58 & 1,19 & 0,00005 & 0,00004 & 1,34 & 0,21 \\
\hline Число вибулих рег. & 0,96 & 1,59 & 0,00003 & 0,000050 & 0,60547 & 0,56 \\
\hline Число прибулих зовн. & 6,43 & 3,14 & 0,0002 & 0,0001 & 2,05 & 0,06 \\
\hline Число вибулих зовн. & $-7,13$ & 3,14 & $-0,0002$ & 0,0001 & $-2,26$ & $0,04^{*}$ \\
\hline Померло до 1 року осіб на 100 & $-1,62$ & 1,81 & $-0,004$ & 0,0044 & $-0,90$ & 0,39 \\
\hline Смертність до 1 року на 1000 & 0,49 & 0,41 & 0,17 & 0,15 & 1,19 & 0,27 \\
\hline
\end{tabular}

Примітка. рег. - регіональна міграція; зовн. - зовнішня міграція; * - p<0,05.

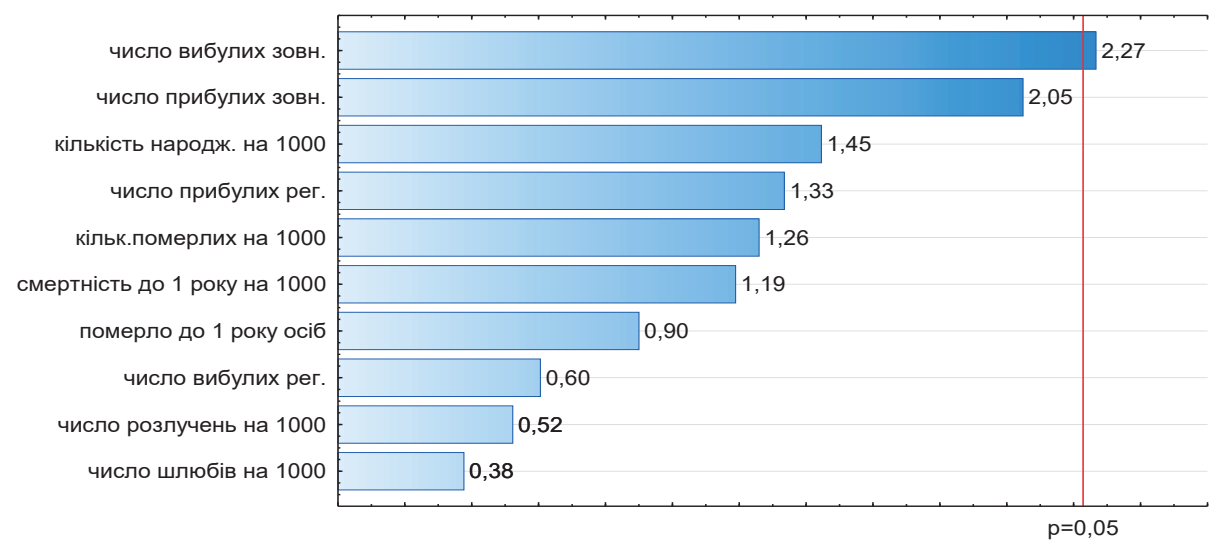

Примітка: Рег. - регіональна міграція; зовн. - зовнішня міграція.

Рис. З. Значення множинних коефіцієнтів регресії внесків у захворюваність дітей на ДАК основних показників міграційних процесів у Запорізькій області. 
Огляди літератури, оригінальні дослідження, погляд на проблему

У дітей сільських районів Запорізької області (табл. 4, рис. 4), внески міграційних процесів у захворюваність на ДАК мали дещо іншу спрямованість. Так, найбільші внески у захворюваність у цій групі хворих характеризували народжуваність на 1000 населення $\left(b^{2}=-1,07 ; p=0,02\right)$ та відповідне збільшення захворюваності при зменшенні народжуваності. Порівняння отриманих коефіцієнтів регресії найпоширеніших ВBC у області, а саме ДМПП та ДМШП, характеризують внески мігра- ційних процесів у відповідну захворюваність, порівняно із внесками у захворюваність на ДАК. Дані представлені у таблиці 5 та на рисунку 5. Як свідчать представлені дані, найбільші внески у захворюваність на ДАК при порівнянні із найпоширенішими ВВС у дітей Запорізької області, такими як ДМПП та ДМШП, стосувались показників зовнішніх міграційних процесів: числа прибулих $\left(b^{2}=6,51\right.$ для клапанних BBC та $b^{2}=3,67$ й $b^{2}=-4,66$ для ДМПП і ДМШП відповідно).

Таблиця 4. Коефіцієнти множинної регресії $\left(b^{2}\right)$, що характеризують внески основних міграційних процесів у захворюваність на ДАК у дітей сільських районів Запорізької області

\begin{tabular}{|l|c|c|c|c|c|c|}
\hline \multicolumn{7}{|c|}{$\mathrm{R}=0,89 ; \mathrm{R}^{2}=0,80 ;$ скоригований $\mathrm{R}^{2}=0,40 ; \mathrm{F}=2,01$} \\
\hline & $\mathrm{b}^{2}$ & $\mathrm{~b}^{2 \pm} \mathrm{m}$ & $\mathrm{b}$ & $\mathrm{b} \pm \mathrm{m}$ & $\mathrm{t}(10)$ & $\mathrm{p}$-value \\
\hline Interсерt & & & 0,30 & 0,11 & 2,72 & $0,04^{*}$ \\
\hline Кількість народж. на 1000 & $-1,07$ & 0,34 & $-0,015$ & 0,005 & $-3,17$ & $0,02^{*}$ \\
\hline Кількість померлих на 1000 & $-0,75$ & 0,41 & $-0,0046$ & 0,002 & $-1,81$ & 0,13 \\
\hline Число шлюбів на 1000 & $-1,05$ & 0,67 & $-0,012$ & 0,008 & $-1,56$ & 0,18 \\
\hline Число розлучень на 1000 & $-0,45$ & 0,35 & $-0,02$ & 0,019 & $-1,28$ & 0,26 \\
\hline Число прибулих рег. & 0,88 & 0,73 & 0,00007 & 0,0006 & 1,20 & 0,28 \\
\hline Число вибулих рег. & 2,15 & 1,31 & 0,00019 & 0,0001 & 1,64 & 0,16 \\
\hline Число прибулих зовн. & $-0,003$ & 0,80 & $-0,000001$ & 0,0002 & $-0,004$ & 0,10 \\
\hline Число вибулих зовн. & $-0,65$ & 0,63 & $-0,00017$ & 0,0002 & $-1,03$ & 0,35 \\
\hline Померло до 1 року осі6 & $-2,24$ & 1,36 & $-0,01$ & 0,007 & $-1,63$ & 0,17 \\
\hline Смертність до 1 року на 1000 & 1,68 & 0,10 & 0,35 & 0,21 & 1,68 & 0,15 \\
\hline
\end{tabular}

Примітка. рег. - регіональна міграція; зовн. - зовнішня міграція; * - p<0,05.

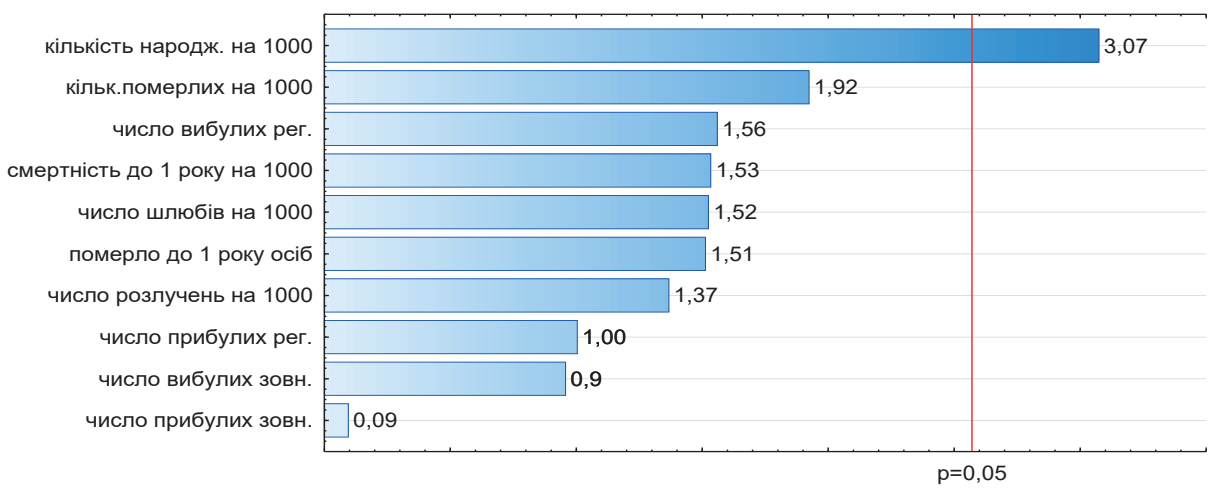

Примітка. Рег. - регіональна міграція; зовн. - зовнішня міграція.

Рис. 4. Значення І множинних коефіцієнтів регресії внесків у захворюваність дітей на ДАК основних показників міграційних процесів у сільських районах Запорізької області.

Таблиця 5. Порівняльні регресійні коефіцієнти внесків міграційних процесів у захворюваність на ДМПП, ДМШП та ДАК у дітей Запорізької області

\begin{tabular}{|c|c|c|c|c|c|c|c|c|c|c|}
\hline $\begin{array}{c}\text { Захво- } \\
\text { рюва- } \\
\text { ність }\end{array}$ & $\begin{array}{c}\text { Кількість } \\
\text { народ. } \\
\text { на } 1000\end{array}$ & $\begin{array}{c}\text { Кільк. } \\
\text { помер- } \\
\text { лих на } \\
1000\end{array}$ & $\begin{array}{c}\text { Число } \\
\text { шлюбів } \\
\text { на } 1000\end{array}$ & $\begin{array}{c}\text { Число } \\
\text { розлу- } \\
\text { чень на } \\
1000\end{array}$ & $\begin{array}{c}\text { Число } \\
\text { приб-- } \\
\text { лих рег. }\end{array}$ & $\begin{array}{c}\text { Число } \\
\text { вибулих } \\
\text { рег. }\end{array}$ & $\begin{array}{c}\text { Число } \\
\text { при- } \\
\text { булих } \\
\text { зовн. }\end{array}$ & $\begin{array}{c}\text { Число } \\
\text { вибулих } \\
\text { зовн. }\end{array}$ & $\begin{array}{c}\text { Помер- } \\
\text { ло до } \\
1 \text { року } \\
\text { осіб }\end{array}$ & $\begin{array}{c}\text { Смерт- } \\
\text { ність до } \\
1 \text { року } \\
\text { на } 1000\end{array}$ \\
\hline ДМПП & $-0,24$ & 0,024 & 0,47 & $-0,93$ & 2,62 & $-0,60$ & 3,67 & $-3,75$ & $-1,71$ & 0,52 \\
\hline ДМШП & $-0,44$ & $-0,85$ & $-1,35$ & 0,47 & $-1,1$ & 3,27 & $-4,66$ & 0,41 & 1,86 & $-0,39$ \\
\hline ДАК & $-0,38$ & $-0,27$ & 0,03 & $-0,26$ & 1,9 & 0,57 & 6,51 & $-6,86$ & $-1,90$ & 0,57 \\
\hline
\end{tabular}

Примітка. Рег. - регіональна міграція; зовн. - зовнішня міграція. 


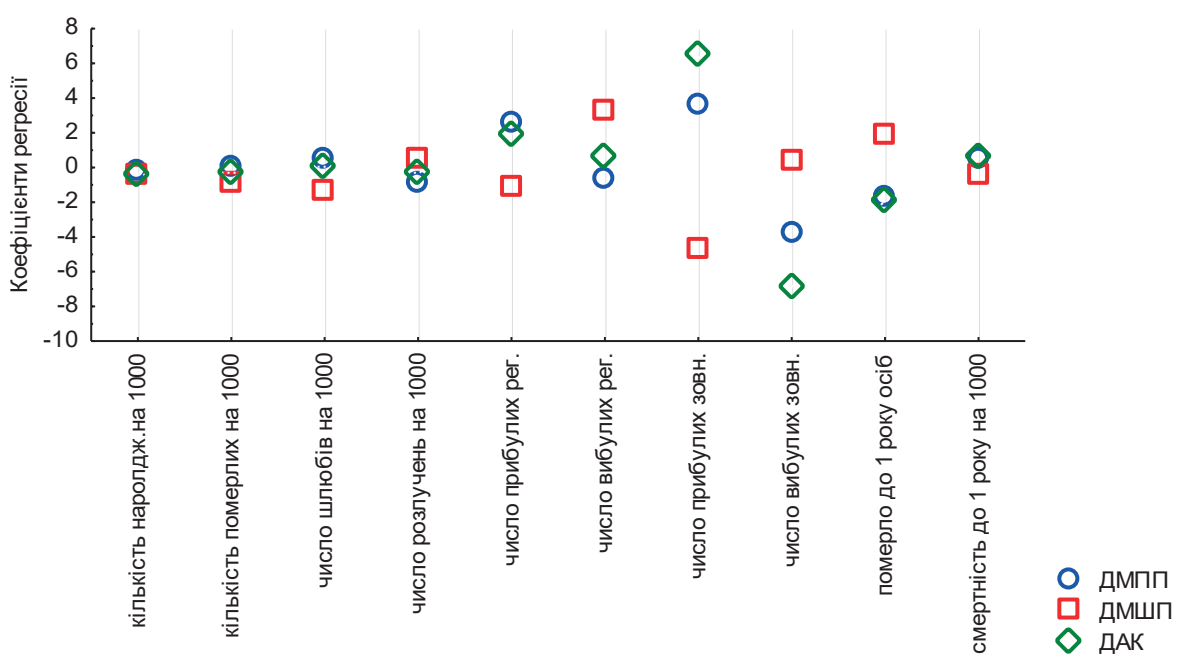

Примітка. Рег. - регіональна міграція; зовн. - зовнішня міграція.

Рис. 5. Порівняльні коефіцієнти регресії внесків міграційних показників у захворюваність на ДМПП, ДМШП та ДАК у дітей Запорізької області.

Таким чином, найбільший вплив на захворюваність на клапанні ВВС у дітей Запорізької області мали процеси зовнішньої міграції, що відбувалися переважно у містах регіону.

Висновки. 1. Міграційні процеси (станом на 2011 рік) у Запорізькій області характеризуються достовірним переважанням показників як внутрішньорегіональної, так й зовнішньої міграції у мешканців міст.

2. Захворюваність на ДАК у дітей міст Запорізької області значно перевищує таку у сільських районах.

3. Серед демографічних показників найбільший вплив мають на захворюваність на ДАК, по-

\section{ЛITEPATУPA}

1. Woodrow Benson D. Genetic origins of pediatric heart disease / D. Woodrow Benson // Pediatr. Cardiol. 2010. - Vol. 31. - P. 422-429.

2. Тимченко О. В. Генофонд і здоров'я: природний і штучний добір серед населення / О. В Тимченко, Т. М. Линчак, О. І. Поканєвич. - К., 2015. - 263 с.

3. Коцур Н. І. Екологічні ризики і здоров'я людини: сучасні проблеми та шляхи розв'язання / Н. І. Коцур // Молодий вчений. - 2016 р. - № 9.1 (36.1). - С. 91-94.

4. High-resolution analysis of copy number variants in adults with simple-to-moderate congenital heart disease. W. Zhao, G. Niu, B. Shen [et al.] // Am. J. Med. Genet. A. 2013. - Vol. 161 A (12). - P. 3087-3094. рівняно із іншими ВВС, число прибулих та вибулих осіб при зовнішній міграції в регіоні.

4. Виявлені особливості впливу міграційних процесів на захворюваність ДАК у дітей Запорізької області свідчать про їх особливу роль у формуванні генетичних чинників гетерозиготності населення. Зазначені демографічні процеси можуть вважатись універсальними щодо вивчення захворюваності на даний тип ВВС у дітей та слугувати непрямим показником мутаційного навантаження у окремих субпопуляціях України.

Перспективою подальших досліджень $\epsilon$ вивчення асоціацій генотипів мешканців регіону $з$ підвищенням захворюваності на ДАК. 
Огляди літератури, оригінальні дослідження, погляд на проблему

\section{REFERENCES}

1. D. Woodrow Benson. (2010). Genetic origins of pediatric heart disease. Pediatr. Cardiol., 31, 422-429.

2. Tymchenko, O.V., Lynchak, T.M., \& Pokanievich, O.I. (2015). Henofond i zdorovia: pryrodnyi i shtuchnyi dobir sered naselennia [Gene pool and health: natural and artificial selection among the population]. Kyiv [in Ukrainian].

3. Kotsur, N.I. (2016). Ekolohichni ryzyky i zdorovia liudyny: suchasni problemy ta shliakhy rozviazannia [Environmental risks and human health: current problems and solutions]. Molodyi vchenyi-Young Scientist, 9.1 (36.1), 9194 [in Ukrainian].

4. Zhao, W., Niu, G., Shen, B., Zheng, Y., Gong, F., Wang, X., Lee, J., Mulvihill, J.J., Chen, X., \& Li, S. (2013). High-resolution analysis of copy number variants in adults with simple-to-moderate congenital heart disease. Am. J. Med. Genet. A., 161 A (12), 3087-3094.

5. Klymenko, T.M., Korovai, S.M., \& Karapetian O.Yu. (2016). Prenatalna diahnostyka yak rezerv vedennia ditei z vrodzhenymy vadamy sertsia [Prenatal diagnosis as a reserve for the management of children with congenital heart disease]. Neonatolohiia, khiruhiia ta perynatalna medytsyna - Neonatology, Surgery and Perinatal Medicine, VI, (2) (20), 20-24 [in Ukrainian].

6. Abdul-Ogly, L.V., \& Svydler, A.L. (2011). Poroki razvitia serdtsa pri narushenii formirovaniya platsenty: monografiya [Congenital heart defects in violation of placenta formation: monograph] [in Russian].

7. Kamenshchyk, A.V., Sheludko, D.M., \& Antishina, L.F. (2013) Pokaznyky rozpovsiudzhenosti vad sertsevo-sudynnoi systemy u ditei u vzaiemozviazku z demohrafichnoiu sytuatsieiu $v$ Zaporizkii oblasti [The signs of the cardiovascular defects prevalence in children in connection with the demographic situation in Zaporizhzhia region]. Ukrainskyi medychnyi almanakh - Ukrainian Medical Almanac, 16 (2), 113-115 [in Ukrainian].

\title{
РЕГИОНАЛЬНЫЕ МИГРАЦИОННЫЕ ПРОЦЕССЫ И ЗАБОЛЕВАЕМОСТЬ ДВУСТВОРЧАТЫМ АОРТАЛЬНЫМ КЛАПАНОМ У ДЕТЕЙ ЗАПОРОЖСКОЙ ОБЛАСТИ
}

\section{๑А. В. Каменщик}

\author{
Запорожский государственный медицинский университет, г. Запорожье
}

РЕЗЮМЕ. Формирование врожденных пороков сердца (ВПС) происходит под влиянием генетических, экологических и демографических факторов. Под влиянием миграционных процессов, благодаря изменениям внутрипопуляционной гетерозиготности увеличиваются мутационные нагрузки, что, в свою очередь, приводит к изменениям в формировании заболеваемости врожденными пороками сердца (ВПС), в том числе двустворчатым аортальным клапаном (ДАК).

Целью исследования стало установление взаимосвязей между основными показателями миграции населения и заболеваемостью двустворчатым аортальным клапаном (ДАК) у городских и сельских жителей Запорожской области, а также вклад в нее процессов миграции населения.

Материал и методы. На основании данных о заболеваемости наиболее распространенными ВПС среди детей Запорожской области, включая двустворчатый аортальный клапан (ДАК), и данных областного управления статистики по показателям миграции населения региона, с использованием методов корреляционного и регрессионного анализа было изучено влияние этих показателей на заболеваемость ДАК.

Результаты. Установлено преобладание внутрирегиональной и внешней миграции у жителей городов региона при достоверном увеличении у них заболеваемости ДАК. Наибольшие вклады в заболеваемость, в том числе по сравнению с другими ВПС, имеет число прибывших и выбывших лиц при внешней миграции. Установлено влияние отдельных миграционныхпроцессов на заболеваемость ДАК, что может служить косвенным показателем мутационной нагрузки в отдельных субпопуляциях Украины.

КЛЮЧЕВЫЕ СЛОВА: двустворчатый аортальный клапан; дети; заболеваемость врожденными пороками сердца; сельское и городское население; вклады миграционных процессов.

\section{REGIONAL MIGRATION PROCESSES AND THE BICUSPID AORTIC VALVE INCIDENCE IN CHILDREN OF ZAPORIZHZHIA REGION}

@A. V. Kamenshchyk

\section{Zaporizhzhia State Medical University}

SUMMARY. The formation of congenital heart disease (CHD) occurs under the influence of genetic, ecological and demographic factors. Under the influence of migration processes, due to changes in intrapopulation heterozygosity, mutational pool increases, which, in turn, leads to changes in the formation of the CHD incidence including the bicuspid aortic valve (BAV). 
Огляди літератури, оригінальні дослідження, погляд на проблему

The aim of the study was to establish the interrelations between the main parameters of populational migration and the incidence of a bicuspid aortic valve (BAV) in urban and rural residents of Zaporizhzhia region, as well as the inputs of populational migration processes to it.

Materials and Methods. Based on the incidence data about the most common CHD among the children of Zaporizhzhia region, including the BAV and data from the regional statistical office on populational migration, using correlation and regression analysis, the effect of these indicators on the BAV incidence was established.

Results and Discussion. The prevalence of intraregional and external migration among residents of the cities of the region is established with a significant increase in their BAV incidence. The largest inputs to morbidity including in comparison with other CHD's has the number of arrival and departure persons in external migration. The influence of some migration processes on the incidence of BAV has been established, which can serve as an indirect indicator of the mutation pool in certain subpopulations of Ukraine.

KEY WORDS: bicuspid aortic valve; children; congenital heart diseases prevalence; rural and urban population; inputs of migration processes.

Отримано 08.08.2017 